\title{
Is Correlation between Plasma and Salivary Cortisol Levels an Important Indicator of Stress? A Meta-Analysis Study
}

\author{
Burcu Köksal \\ Lokman Hekim University, Department of Physiology, Ankara, Turkey
}

\author{
SUMMARY
}

The purpose of this study was to examine the practical importance of the correlation values between plasma and salivary cortisol levels using meta-analysis study. In this way, researchers focusing on cortisol levels in different individuals can use more systemic, practical and reliable evidence than using just salivary or plasma cortisol levels separately. For this purpose, correlational studies from 2000 up to now were collected and analyzed by meta-analysis. Results based on 18 effect sizes $(n=743)$ revealed that effect sizes of the correlations between plasma and salivary cortisol levels represented large effects. The overall combined effect size (Hedges's $=1.55$ ) also represented a large effect. This finding indicates the practical importance of the correlation values for stress studies. The use of the correlation values for examining the cortisol levels in stress studies will be discussed in detail.

Key words: stress, salivary cortisol, plasma cortisol, meta-analysis

Corresponding author:

Burcu Köksal

e-mail: burcu.koksal@lokmanhekim.edu.tr 


\section{INTRODUCTION}

Stress can be defined "as a state in which an organism's internal regulatory balance (or homeostasis) is disturbed by real or perceived challenges in its external environment" (1). Stress is an important factor in todays' competitive and complex life of people. Its negative effects are frequently seen on happiness (2), sleep quality, daytime dysfunction (3) and working memory (4). Stress is also a risk factor for depression (5). Stress can be classified as psychological and physical stress and their existence activates the hypothalamic-pituary-adrenal axis and autonomic nervous system (6). Based on this activation, stress response occurs and hence increased $\mathrm{ACTH}$, cortisol and arginine vasopressin are observed $(7,8)$. Especially, cortisol levels are frequently the biomarker of stress levels (9 - 11). Dickerson, Gruenevald and Kemeny stated that cortisol response peaks in 20 and $40 \mathrm{~min}$ after the beginning of stressful experience (12). Cortisol levels in stress studies are frequently determined by examining plasma and salivary cortisol levels $(13,14)$. The important point here is to decide about using a change in total cortisol level, a change in free cortisol levels or both of them. In saliva, cortisol is found in a free form and the levels of cortisol in saliva are correlated with the total cortisol level in changing amounts (15). In addition, the range of the correlation values between plasma and salivary cortisol levels as different stress biomarkers of the same bio system are also high $(13,16)$. Therefore, the practical importance of correlation values between plasma and salivary cortisol levels stands as a valuable research subject for stress studies. Actually, the cortisol level in saliva makes about $50-60 \%$ of free cortisol in plasma and they are rooted from the adrenocortical function as response to stress. Hence, the levels of cortisol in saliva and plasma are highly correlated (17). Measurement of cortisol levels after stressful events needs a systemic approach by taking into account changes in cortisol levels in different parts of the body system. Taking cortisol samples from related parts of the system might lead to additional stress (i.e. taking blood samples or using surgery) or invalid measurement (insufficiencies in exemplifying the total amount of cortisol). The correlation between different cortisol measurements might be an option to predict stress-dependent changes in cortisol levels in the whole system. Therefore, the purpose of this study was to investigate the practical importance of correlation values between plasma and salivary cortisol levels using meta-analysis study.

\section{METHOD}

In this study, meta-analysis was applied to the correlation values reported by different studies published in the last 20 years. Meta-analysis is a way of statistically synthesizing findings of previously conducted studies (18). By using meta-analysis, findings of independent studies are combined by decreasing limitations in the scope of studies. In this study, effect sizes regarding the correlation values on plasma and salivary cortisol levels in independent studies were calculated. Then, their practical importance was analyzed by examining the size of a combined effect size. Before the analysis, all Spearman correlations were converted into Pearson correlation values.

First, inclusion criteria and key words for the studies were defined. The words were "correlation", "cortisol levels", "plasma cortisol level", "salivary cortisol level" and "stress". These words were investigated in PubMed, Google Scholar, ULAKBIM and EBSCO. The time interval was from 2000 to 2020. As the inclusion criteria, the following rules were applied to the studies found in the databases:

1. Publications involving human subjects

2. Publications reporting correlation coefficients (Spearman or Pearson)

3. Publications reporting cortisol levels with standard error of measurement

\section{Publications after 2000.}

After the literature search, 15 studies (18 effect sizes) published in different journals between 2000 and 2018 were selected. The studies involved in meta-analysis are represented with "*" asterisk in the list of references. The total number of participants in the studies was 743. Descriptive values regarding the studies are reported in Table 1.

As can be seen in Table 1, all of the correlations are positive. For making the meta-analysis reliable and valid, another independent coder also coded the studies based on inclusion criteria. Two independent coders reached high consensus. Then, bias for publication selection was checked by examining a funnel plot. The funnel plot analysis is represented in Figure 1.

As seen in Figure 1, standard errors of the individual standard errors of Hedges's $g$ are scattered symmetrically on the overall effect size value. Other- 


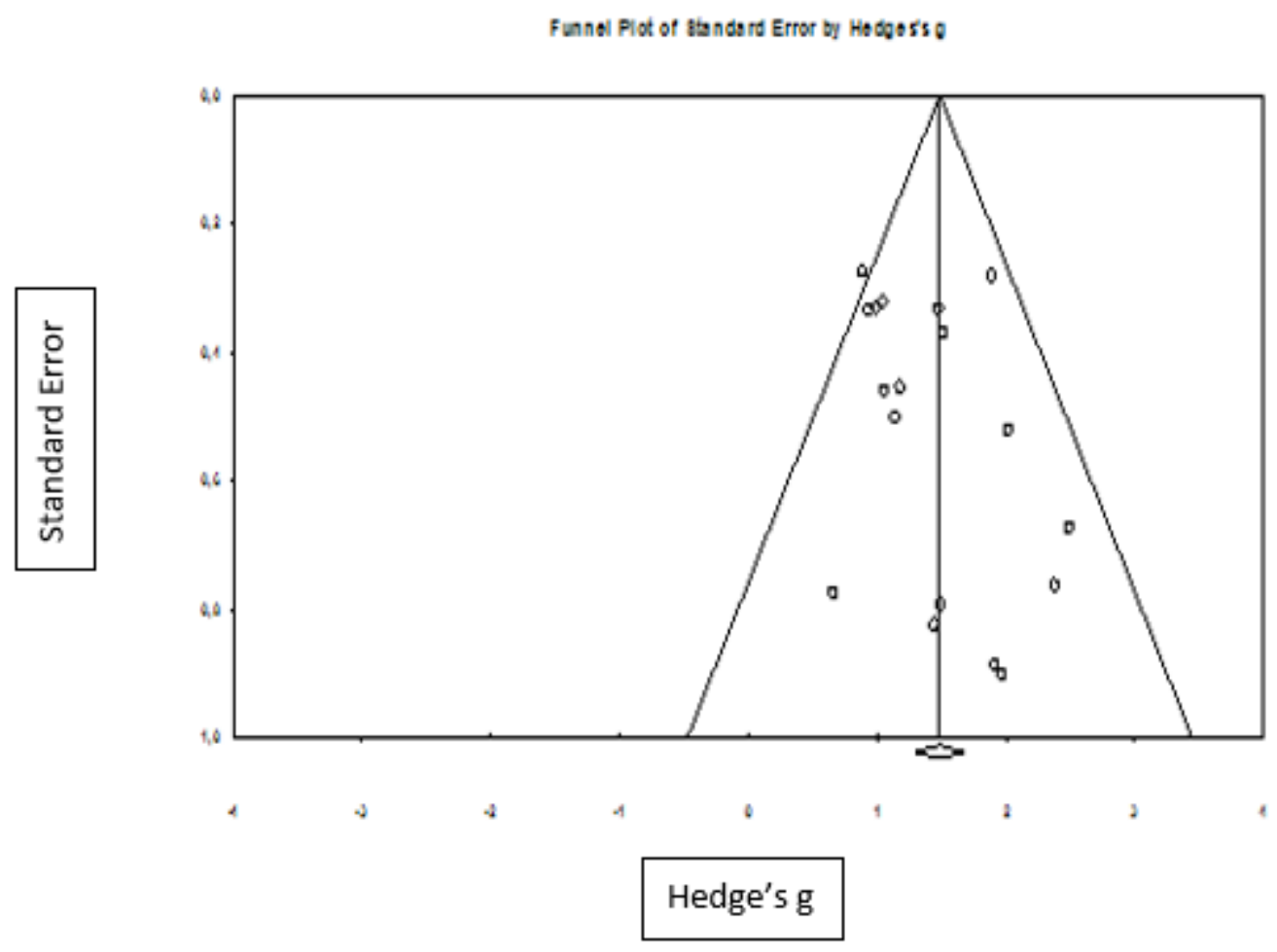

Figure 1. Funnel plot of 15 studies examining correlation values between plasma and salivary cortisol levels

wise, the accumulation of the values on one side of the graph should be seen (31). In analysis of the relationships, the overall effect size was calculated by using a meta-analysis software (CMA-Version 2.0). Effect size is a basic unit of meta-analysis and can be defined as magnitude of a result regarding a relationship or difference as it would be found in population (32). In meta-analysis of correlational studies, the method of analysis should be chosen after performing a heterogeneity test. In this study, Q-value and I2 values were calculated to decide about heterogeneity. The findings are given in Table 2.
Table 2 shows that Q-value is significant and I2 value is 57,92 . These results indicate a moderate level of heterogeneity $(31,18)$. The expected results for homogeneity were non-significant Q-value and $0 \%$ for I2 (30). By considering moderate heterogeneity, the use of random effects model was determined. Hedges's g was used as an effect size value in this study. Calculated effect sizes are interpreted as follows: " $.00-.15$ " - no effect, " .16 - .38" - small effect, " .39- .69" - medium effect, " .70 - 1.00" - large effect (31). 
Table 1. Descriptive values regarding the studies providing inclusion criteria

\begin{tabular}{|c|c|c|c|c|c|c|}
\hline $\begin{array}{c}\text { Research } \\
\text { citation }\end{array}$ & \begin{tabular}{|l|} 
Correlation \\
magnitude
\end{tabular} & Salivary cortisol level & Plasma cortisol level & Participants & $\begin{array}{c}\text { Sample } \\
\text { size }\end{array}$ & Correlation \\
\hline (19) & $\mathrm{r}=0.41$ & $\begin{array}{c}127.5 \mathrm{nmol} / \mathrm{L} \pm 66.5 \\
\mathrm{SEM}\end{array}$ & $\begin{array}{c}\text { 400nmol/L } \pm 42.8 \\
\mathrm{SEM}\end{array}$ & $\begin{array}{c}\text { Infants } \\
(25.3 \pm 1.3 \text { weeks })\end{array}$ & 65 & Pearson \\
\hline$(20)$ & $\mathrm{r}=0.61$ & $1.0 \pm 0.8 \mathrm{SEM} \mu \mathrm{g} / \mathrm{dL}$ & $\begin{array}{c}12.3 \mu \mathrm{g} / \mathrm{dL} \pm 6.4 \\
\mathrm{SEM}\end{array}$ & $\begin{array}{c}\text { Infants } \\
(3-7 \text { days }) \\
\end{array}$ & 48 & Pearson \\
\hline$(21)$ & $r=0.63$ & $24.4 \pm 5.4 \mathrm{nmol} / 1$ & $16.4 \pm 2.0 \mu \mathrm{g} / 100 \mathrm{ml}$ & $\begin{array}{c}\text { Healthy individuals } \\
(21-62 \text { ages })\end{array}$ & 12 & Pearson \\
\hline$(22)$ & $\mathrm{r}=0.69$ & $8.9(6.5-10.0) \mathrm{ng} / \mathrm{ml}$ & $\begin{array}{c}15.4(14.1-18.1) \\
\mu \mathrm{g} / \mathrm{dl}\end{array}$ & $\begin{array}{l}\text { Adults with adrenal } \\
\text { insuffiency } \\
(54 \pm 10 \text { ages })\end{array}$ & 98 & Spearman \\
\hline$(16)$ & $\mathrm{r}=0.72$ & $0.256 \pm 0.168(\mu \mathrm{g} / \mathrm{dL})$ & $12.2 \pm 5.4(\mu \mathrm{g} / \mathrm{dl})$ & $\begin{array}{l}\text { Aerobically trained } \\
\text { males (18 - } 30 \text { ages) } \\
\end{array}$ & 12 & Pearson \\
\hline (13) & $\mathrm{r}=0.43$ & $21.1 \pm 6.5 \mathrm{pmol} / \mathrm{L}$ & $\begin{array}{c}434 \pm 140 \\
\mathrm{nmol} / \mathrm{L} \\
\end{array}$ & \begin{tabular}{|c|}
$\begin{array}{c}\text { Healthy male athletes } \\
(18.1 \pm 1.2 \text { years })\end{array}$ \\
\end{tabular} & 45 & Pearson \\
\hline (13) & $\mathrm{r}=0.48$ & $20.4 \pm 3.9 \mathrm{pmol} / \mathrm{L}$ & $381 \pm 94.2 \mathrm{nmol} / \mathrm{L}$ & $\begin{array}{c}\text { Healthy female athletes } \\
(17.6 \pm 1.2 \text { years })\end{array}$ & 26 & Pearson \\
\hline (23) & $\mathrm{r}=0.45$ & $\begin{array}{c}10.82( \pm 8.27 \mathrm{SD}) \\
\mathrm{nmol} / 1\end{array}$ & $\begin{array}{c}515.7 \\
( \pm 322.6 \mathrm{SD}) \mathrm{nmol} / \mathrm{l} \\
\end{array}$ & $\begin{array}{c}\text { Individuals with panic } \\
\text { disorder }\end{array}$ & 47 & Spearman \\
\hline$(23)$ & $\mathrm{r}=0.51$ & $6.80(3.45) \mathrm{nmol} / \mathrm{l}$ & $364.9(164.5) \mathrm{nmol} / \mathrm{l}$ & Healthy individuals & 23 & Spearman \\
\hline$(24)$ & $\mathrm{r}=0.73$ & $19 \pm 4 \mathrm{nmol} / \mathrm{L}$ & $505 \pm 46 \mathrm{nmol} / \mathrm{L}$ & $\begin{array}{c}\text { Healthy individuals } \\
(44.7 \pm 4.6)\end{array}$ & 12 & Pearson \\
\hline$(25)$ & $\mathrm{r}=0.72$ & - & - & \begin{tabular}{|c|} 
Healthy individuals \\
$(31.17 \pm 11.12$ ages $)$ \\
\end{tabular} & 32 & Pearson \\
\hline$(25)$ & $\mathrm{r}=0.87$ & - & - & $\begin{array}{c}\text { Individuals with panic } \\
\text { disorder } \\
(32.87 \pm 11.23 \text { ages }) \\
\end{array}$ & 32 & Pearson \\
\hline (26) & $\mathrm{r}=0.79$ & $7.2 \pm 0.9 \mathrm{nmol} / \mathrm{L}$ & $507 \pm 20 \mathrm{nmol} / \mathrm{L}$ & \begin{tabular}{|c|} 
Soccer players \\
$(27 \pm 1$ year $)$ \\
\end{tabular} & 25 & Pearson \\
\hline$(27)$ & $\mathrm{r}=0.52$ & $1.39+0.75 \mu \mathrm{g} / \mathrm{dl}$ & $27.82+5.90 \mu \mathrm{g} / \mathrm{dl}$ & $\begin{array}{c}\text { Healthy individuals } \\
(40 \pm 4 \text { Years })\end{array}$ & 28 & Pearson \\
\hline$(28)$ & $\mathrm{r}=0.47$ & $22.3 \pm 16.4(\mathrm{nmol} / \mathrm{l})$ & $676.3 \pm 259.8(\mathrm{nmol} / \mathrm{l})$ & $\begin{array}{c}\text { Healthy individuals } \\
(23.7 \pm 2.5 \text { years })\end{array}$ & 51 & Pearson \\
\hline$(29)$ & $\mathrm{r}=0.82$ & $27.6 \pm 12.1 \mathrm{nmol} / 1$ & - & Healthy individuals & 110 & Pearson \\
\hline (14) & $\mathrm{r}=0.60$ & $0.43 \pm 0.24(\mu \mathrm{g} / \mathrm{dl})$ & $6.7 \pm 4.2(\mu \mathrm{g} / \mathrm{dl} 9$ & $\begin{array}{c}\text { Preterm infants } 31.4 \\
(28.1-32.7) \text { weeks } \\
\end{array}$ & 58 & Spearman \\
\hline$(30)$ & $\mathrm{r}=0.78$ & $8.311 \pm 5.232 \mathrm{nmol} / \mathrm{L}$ & $202.3 \pm 121.5 \mathrm{nmol} / \mathrm{L}$ & $\begin{array}{c}\text { Very low birth weight } \\
\text { infants } \\
\text { (less than } 29 \text { weeks) }\end{array}$ & 19 & Pearson \\
\hline
\end{tabular}

Table 2. Results about the heterogeneity test of the effect sizes

\begin{tabular}{c|c|c|c}
\hline \hline \multicolumn{4}{c}{ Heterogeneity } \\
\hline Q-Value & $\mathrm{df}(\mathrm{Q})$ & $\mathrm{p}$-value & $\mathrm{I}^{2}$ \\
\hline 45,16 & 17 & 0,001 & 57,92 \\
\hline \hline $\mathrm{p}<.05$
\end{tabular}




\section{RESULTS}

Combined effect sizes regarding the correlations between plasma and salivary cortisol levels in random effects model in $95 \%$ confidence interval were determined. $Z$ and $p$ values regarding the associations can be seen in Table 3 .
According to Table 3, all of the individual effect sizes regarding the relationship between plasma and salivary cortisol levels are statistically significant. Moreover, combined effect size (Hedges's =1.55)

Table 3. Statistical findings regarding effect sizes, $Z$ and $p$ values in $95 \%$ confidence interval

\begin{tabular}{c|c|c|c|c|c|c|c}
\hline \hline \multicolumn{7}{c}{$95 \%$ Confidence Interval } \\
\hline $\begin{array}{c}\text { Research } \\
\text { citations }\end{array}$ & Hegdes's g & $\begin{array}{c}\text { Standard } \\
\text { error }\end{array}$ & Variance & $\begin{array}{c}\text { Lower } \\
\text { lim. }\end{array}$ & $\begin{array}{c}\text { lpper } \\
\text { lim. }\end{array}$ & $\mathrm{Z}$ & $\mathrm{p}$ \\
\hline$(19)$ & .88 & 0.27 & 0.07 & 0.34 & 1.42 & 3.22 & 0.00 \\
\hline$(20)$ & 1.51 & 0.37 & 0.13 & 0.78 & 2.24 & 4.09 & 0.00 \\
\hline$(21)$ & 1.49 & 0.79 & 0.62 & 0.05 & 3.05 & 1.89 & 0.05 \\
\hline$(22)$ & 1.89 & 0.28 & 0.07 & 1.34 & 2.44 & 6.72 & 0.00 \\
\hline$(16)$ & 1.91 & 0.88 & 0,78 & 0.17 & 3.65 & 2.16 & 0.03 \\
\hline$(13)$ & 0.93 & 0.33 & 0.11 & 0.27 & 1.59 & 2.78 & 0.00 \\
\hline$(13)$ & 1.06 & 0.46 & 0.21 & 0.15 & 1.96 & 2.30 & 0.02 \\
\hline$(23)$ & 0.99 & 0.33 & 0.11 & 0.34 & 1.64 & 2.98 & 0.00 \\
\hline$(23)$ & 1.14 & 0.50 & 0.25 & 0.16 & 2.12 & 2.28 & 0.02 \\
\hline$(24)$ & 1.97 & 0.90 & 0.81 & 0.20 & 3.73 & 2.19 & 0.02 \\
\hline$(25)$ & 2.01 & 0.52 & 0.27 & 1.00 & 3.04 & 3.87 & 0.00 \\
\hline$(25)$ & 3.44 & 0.73 & 0.53 & 2.00 & 4.87 & 4.68 & 0.00 \\
\hline$(26)$ & 2.49 & 0.67 & 0.45 & 1.17 & 3.81 & 3.70 & 0.00 \\
\hline$(27)$ & 1.18 & 0.45 & 0.20 & 0.29 & 2.07 & 2.60 & 0.00 \\
\hline$(28)$ & 1.04 & 0.32 & 0.10 & 0.41 & 1.68 & 3.25 & 0.00 \\
\hline$(29)$ & 2.84 & 0.33 & 0.11 & 2.18 & 3.50 & 8.48 & 0.00 \\
\hline$(14)$ & 1.48 & 0.33 & 0.11 & 0.82 & 2.13 & 4.45 & 0.00 \\
\hline$(30)$ & 2.38 & 0.76 & 0.58 & 0.88 & 3.87 & 3.12 & 0.00 \\
\hline $\begin{array}{c}\text { Random } \\
\text { effects model }\end{array}$ & 1.55 & 0.16 & 0.02 & 1.24 & 1.86 & 9.72 & 0.00 \\
\hline \hline $\mathrm{p}<0.05$ indicates a significant result & & & & & \\
\hline
\end{tabular}

is also statistically significant. The findings of the study revealed that effect sizes of the correlations between plasma and salivary cortisol levels represented large effects. The overall combined effect size also represented a large effect.

\section{DISCUSSION}

The findings of this study supported the idea that practical importance of correlation values between plasma and salivary cortisol levels exists and it is possible to use it for determining the degree of physiological stress in human subjects. Based on the large effect of combined effect size regarding the correlation values, it can be claimed that the subjects of previous studies experienced certain physiological stress and the levels of the stress in body were practically important (Hedges's $=1.55$ ). The findings reveal that when level of cortisol in saliva increases, the level of cortisol in plasma increases as well. Actually, the cortisol level in saliva makes about 50$60 \%$ of the free cortisol in plasma (17). We know that stressful conditions activate hypothalamic-pituaryadrenal axis and autonomic nervous system (6). Then, 
stress response increases the levels of ACTH, cortisol and arginine vasopressin $(7,8)$. The important point in this pathway is that cortisol levels in plasma and saliva are affected in the same degree since the correlational findings point to the existence of unexplained variance between plasma and salivary cortisol levels $(13,23)$. Here the researchers have to be cautious about deciding on the degree of stress in the whole body system. Difference effects of stress in different parts of the body system might occur. Hence there is a need to study stress by considering the changes in cortisol levels in different parts of the body. In this way, better inferences than inferences made by just looking at salivary cortisol levels might be drawn. I can suggest that the effect size (Hedges's) regarding correlational values between plasma and salivary cortisol levels might be an important biomarker for stress studies with humans. A large effect might be a criterion for deciding about the practical importance of the stress response in plasma and saliva.

\section{CONCLUSION}

This study reported that correlational values between plasma and salivary cortisol levels are important for studying candidate for studying stress with human subjects. A large effect size shows us that the correlation between plasma and salivary cortisol levels represent a valuable criterion for prac- tical importance of the stress response in plasma and saliva. Hence there is a need to develop models explaining changes in correlations between plasma and salivary cortisol levels and changes in stress response in future studies.

This study is based on two parameters (cortisol levels in two different locations of body system), so there is a need to consider other indicators of stress in the body system. Then, more complete picture about the effect of stress on the whole system might be seen. Therefore, I can recommend, when future studies are concerned, to increase the number of parameters regarding stress. In this study, metaanalysis was applied, however, there are other ways of studying the correlation values such as path analysis. In future studies, path analysis or canonical correlation might be applied to larger samples of correlational studies than was the sample of this study. Another important point in this study is the limitation regarding the number of studies examined. This study is limited to 15 studies, so there is a need to increase the number of studies calculating the correlation between plasma and salivary cortisol levels. It is also important that this study reported the correlational values in the articles on both healthy and unhealthy individuals. Future researchers should be cautious when separating the findings of the studies on healthy and unhealthy individuals. 


\section{References}

1. Ali N, Pruessner JC. The salivary alpha amylase over cortisol ratio as a marker to assess dysregulations of the stress systems. Physiol Behav 2012; 106(1): 65-72.

https://doi.org/10.1016/j.physbeh.2011.10.003

2. Lee MY. The Effects of stress on happiness in university students-moderating effects of family healthiness. J. Korea Con Assoc 2019; 19(3): 55765.

3. Thorsteinsson EB, Brown RF, Owens MT. Modeling the effects of stress, anxiety, and depression on rumination, sleep, and fatigue in a nonclinical sample. J Nerv Ment Dis 2019; 207(5): 355-9.

https://doi.org/10.1097/NMD.0000000000000973

4. Almela M, Hidalgo V, Villada C, et al. The impact of cortisol reactivity to acute stress on memory: Sex differences in middle-aged people. Stress 2011; 14(2): 117-27.

https://doi.org/10.3109/10253890.2010.514671

5. Hammen C, Kim EY, Eberhart NK, et al. Chronic and acute stress and the prediction of major depression in women. Depress Anxiety 2009; 26:718-23.

https://doi.org/10.1002/da.20571

6. Singh A, Petrides JS, Gold PW, et al. Differential hypothalamic-pituitary-adrenal axis reactivity to psychological and physical stress. J Clin Endocrinol Metab 1999; 84(6): 1944-8.

https://doi.org/10.1210/jc.84.6.1944

7. Altemus M, Roca C, Galliven E, et al. Increased vasopressin and adrenocorticotropin responses to stress in the midluteal phase of the menstrual cycle. J Clin Endocrinol Metab 2001; 86(6): 252530.

\section{https://doi.org/10.1210/jcem.86.6.7596}

8. Hellhammer DH, Wüst S, Kudielka BM. Salivary cortisol as a biomarker in stress research. Psychoneuroendocrinology 2009; 34(2): 163-71. https://doi.org/10.1016/j.psyneuen.2008.10.026

9. Asbrand J, Heinrichs N, Nitschke K, et al. Repeated stress leads to enhanced cortisol stress response in child social anxiety disorder but this effect can be prevented with CBT.

Psychoneuroendocrinology 2019; 109: 104352. https://doi.org/10.1016/j.psyneuen.2019.06.003

10. Volkan B, Bayrak NA, Ucar C, et al. Preparatory information reduces gastroscopy-related stress in children as confirmed by salivary cortisol. Saudi J Gastroenterol 2019, 25(4): 262. https://doi.org/10.4103/sjg.SJG 49318

11. Ozgocer T, Yildiz S, Ucar C. Development and validation of an enzyme-linked immunosorbent assay for detection of cortisol in human saliva. J Immunoassay Immunochem 2017, 38(2): 147-64. https://doi.org/10.1080/15321819.2016.1230130

12. Dickerson SS, Gruenewald TL, Kemeny ME. When the social self is threatened: Shame, physiology, and health. J Pers 2004; 72(6): 1191216.

https://doi.org/10.1111/j.1467-6494.2004.00295.x

13. Crewther BT, Obmiński Z, Orysiak J, et al. The utility of salivary testosterone and cortisol concentration measures for assessing the stress responses of junior athletes during a sporting competition. J Clin Lab Anal 2018; 32(1): e22197. https://doi.org/10.1002/jcla.22197

14. Maas C, Ringwald C, Weber K, et al. Relationship of salivary and plasma cortisol levels in preterm infants: results of a prospective observational study and systematic review of the literature. Neonatology 2014; 105(4): 312-8. https://doi.org/10.1159/000357555

15. Törnhage CJ. Salivary cortisol for assessment of hypothalamic-pituitary-adrenal axis function. Neuroimmunomodulation 2009; 16(5): 284-9. https://doi.org/10.1159/000216186 
16. Van Bruggen MD, Hackney AC, McMurray RG, et al. The relationship between serum and salivary cortisol levels in response to different intensities of exercise. Int J Sports Physiol Perform 2011; 6: 396-407.

https://doi.org/10.1123/ijspp.6.3.396

17. Umeda $T$, Hiramatsu R, Iwaoka $T$, et al. Use of saliva for monitoring unbound free cortisol levels in serum. Clin Chim Acta 1981;110:245-53.

https://doi.org/10.1016/0009-8981(81)90353-3

18. Cooper H, Hedges LV, Valentine JC. The handbook of research synthesis and meta-analysis (2nd edition). New York: Russell Sage Publication. 2009.

19. Ng SM, Drury J, Upradrasta S, et al. Correlation of plasma and salivary cortisol in extremely premature infants. J Neonatal Biol 2017; 6(260): 2167-0897.

https://doi.org/10.4172/2167-0897.1000260

20. Calixto C, Martinez FE, Jorge SM, et al. Correlation between plasma and salivary cortisol levels in preterm infants. J Pediatr 2002;140(1): 116-8.

https://doi.org/10.1067/mpd.2002.120765

21. Bhagwagar Z, Hafizi S, Cowen P. Acute citalopram administration produces correlated increases in plasma and salivary cortisol. Psychopharmacology 2002; 163(1): 118-20. https://doi.org/10.1007/s00213-002-1149-4

22. Galbois A, Rudler M, Massard J, et al. Assessment of adrenal function in cirrhotic patients: salivary cortisol should be preferred. J Hepatol 2010; 52(6): $839-45$.

https://doi.org/10.1016/j.jhep.2010.01.026

23. Wedekind D, Bandelow B, Broocks A, et al. Salivary, total plasma and plasma free cortisol in panic disorder. J Neural Transm 2000; 107(7): 8317.

https://doi.org/10.1007/s007020070062

24. Jung C, Greco S, Nguyen HH, et al. Plasma, salivary and urinary cortisol levels following physiological and stress doses of hydrocortisone in normal volunteers. BMC Endocr Disord 2014; 14(1): 1-10.

https://doi.org/10.1186/1472-6823-14-91

25. Petrowski K, Wintermann GB, Schaarschmidt M, et al. Blunted salivary and plasma cortisol response in patients with panic disorder under psychosocial stress. Int J Psychophysiol 2013; 88(1): 35-9.

https://doi.org/10.1016/j.ijpsycho.2013.01.002

26. Lippi G. De Vita F, Salvagno GL, et al. Measurement of morning saliva cortisol in athletes. Clin Biochem 2009; 42(9): 904-6. https://doi.org/10.1016/j.clinbiochem.2009.02.012

27. Cadore E, Lhullier F, Brentano M, et al. Correlations between serum and salivary hormonal concentrations in response to resistance exercise. J Sports Sci 2008; 26(10): 1067-72. https://doi.org/10.1080/02640410801919526

28. Rantonen PJ, Penttilä I, Meurman JH, et al. Growth hormone and cortisol in serum and saliva. Acta Odontol Scand 2000; 58(6): 299-303. https://doi.org/10.1080/00016350050217163

29. Westermann J, Demir A, Herbst V. Determination of cortisol in saliva and serum by a luminescenceenhanced enzyme immunoassay. Clin Lab 2004; 50(1-2): 11-24.

30. Matsukura T, Kawai M, Marumo C, et al. Diagnostic value of salivary cortisol in the $\mathrm{CRH}$ stimulation test in premature infants. J Clin Endocrinol Metab 2012; 97(3): 890-6.

https://doi.org/10.1210/jc.2011-1814

31. Borenstein M, Hedges LV, Higgins JPT, et al. Introduction to meta-analysis. West Sussex-UK: John Wiley \& Sons Ltd. 2009.

https://doi.org/10.1002/9780470743386

32. Ellis PD. The essential guide to effect sizes: Statistical power, meta-analysis, and the interpretation of research results. Cambridge University Press.2010. https://doi.org/10.1017/CBO9780511761676 
33. Hardy RJ, Thompson SG. Detecting and describing heterogeneity in meta-analysis. Stat Med 1998; 17(8): 841-56.
https://doi.org/10.1002/(SICI)10970258(19980430)17:8<841::AID-SIM781>3.0.CO;2-D

\title{
Da li je korelacija između nivoa kortizola u plazmi i pljuvačci zapravo važan indikator stresa? Metaanaliza
}

\author{
Burcu Köksal \\ Univerzitet Lokman Hekim, Departman za fiziologiju, Ankara, Turska
}

\section{S AŽETAK}

Cilj ove studije bilo je ispitivanje praktičnog značaja korelacionih vrednosti između nivoa kortizola u plazmi i pljuvačci primenom metaanalize. Na ovaj način, istraživači koji se fokusiraju na nivoe kortizola kod različitih osoba mogu da koriste sistematičnije, praktičnije i pouzdanije dokaze nego što je upotreba podataka o pojedinačnim nivoima kortizola u plazmi i pljuvačci. Iz ovog razloga sakupljene su korelacione studije od 2000. godine do sada $i$ analizirane primenom metaanalize. Rezultati bazirani na 18 efektivnih veličina $(n=743)$ pokazali su da su efektivne veličine korelacija između nivoa kortizola u plazmi i pljuvačci bile velike. Ukupna kombinovana efektivna veličina (Hedges's $=1.55$ ) takođe je predstavljala veliki efekat. Ovaj nalaz ukazuje na praktični značaj korelacionih vrednosti za studije koje ispituju stres. Upotreba korelacionih vrednosti za ispitivanje nivoa kortizola u studijama o stresu biće detaljno analizirana.

Ključne reči: stres, kortizol iz pljuvačke, kortizol iz plazme, metaanaliza 